\title{
Unravelling the Paediatric and Perinatal Zika Virus Epidemic through Population-based Research \\ CDC Christie $^{1}$, C Giaquinto ${ }^{2}$
}

\begin{abstract}
Zika virus epidemic now involves 72 countries, worldwide. Transmission is multimodal through mosquito bites and blood and body fluids. Zika virus causes Guillain Barre syndrome and preg-nancy complications including perinatal microce phaly. Diagnosis is complicated by subclinical infection in 80\%, co-circulation with dengue and chikunguny a fevers with similar presentations and cross-reactivity in serological te sts. There is no cure, or preventive vaccine. Large population-based studies will help to elucidate ZIKV epidemiology, vertical transmission, risks to the fetus of maternal ZIKV infection and natural history of congenital and non-congenital ZIKV infection as provided by the activities in the "ZIKAction" research consortium in Latin America, Europe and the Caribbean, which was recently funded by the European Commission.
\end{abstract}

Key words: Caribbean, child, Zika virus, Guillain-Barre syndrome, microcephaly, pregnancy

\section{Desentrañando la Epidemia Pediátrica y Perinatal del Virus del Zika Mediante una Investigación Poblacional

\author{
CDC Christie ${ }^{1}$, C Giaquinto ${ }^{2}$
}

\begin{abstract}
RESUMEN
En el presente, la epidemia del virus Zika abarca 72 países a nivel mundial. La transmisión es multimodal a través de las picaduras de mosquito, la sangre y los fluidos corporales. El ZIKV causa el síndrome de Guillain-Barré y complicaciones del embarazo, incluyendo la microcefalia perinatal. El diagnóstico se complica por infección subclínica en $80 \%$, y la co-circulación de las fiebres de dengue y chikungunya, con similitud de las manifestaciones y la reactividad en las pruebas serológicas. No existe cura ni vacuna preventiva. Los estudios poblacionales a gran escala ayudarán a dilucidar la epidemiología del $Z I K V$, su transmisión vertical, y los riesgos que para el feto tienen la infección materna de ZIKV y la historia natural de la infección congénita y no congénita por ZIKV. Un ejemplo de tales estudios es el que ofrecen las actividades del Consorcio de investigación "ZIKAction" en América Latina, Europa y el Caribe recientemente financiado por la Comisión Europea.
\end{abstract}

Palabras claves: Caribe, niño, virus del Zika, síndrome de Guillain-Barré, microcefalia, embarazo

West Indian Med J 2016; 65 (1): 239

\section{INTRODUCTION}

Zika virus (ZIKV), an arbovirus of the flavivirus family, has spread explosively through the Americas since it was first identified in Brazil in 2014 (1, 2). As of September 1, 2016, some

From: 'Department of Child and Adolescent Health, The University of the West Indies, Kingston 7, Jamaica and ${ }^{2}$ Department of Women and Child Health, University of Padova, Padova, Italy.

Correspondence: Professor Celia DC Christie, Department of Child and Adolescent Health, The University of the West Indies, Kingston 7, Jamaica, Facsimile, Fax: 876977 5784, E-mail: Celia.ChristieSamuels@uwimona.edu.jm
72 countries worldwide, are reporting local transmission and territories are reporting mosquito-borne ZIKV transmission since 2007, 69 with reports from 2016 and 55 with a first outbreak since 2015 and 47 of these countries are in the Americas, including the mainland of the United States of America and also the Caribbean [Figure] (1). Over four million cases of ZIKV infection were projected to occur in the Americas this year, when "a public health emergency of international concern" was declared by the World Health Organization on February 1, to elucidate the links between ZIKV and congenital microcephaly and Guillain Barre syndrome syndrome (3). 


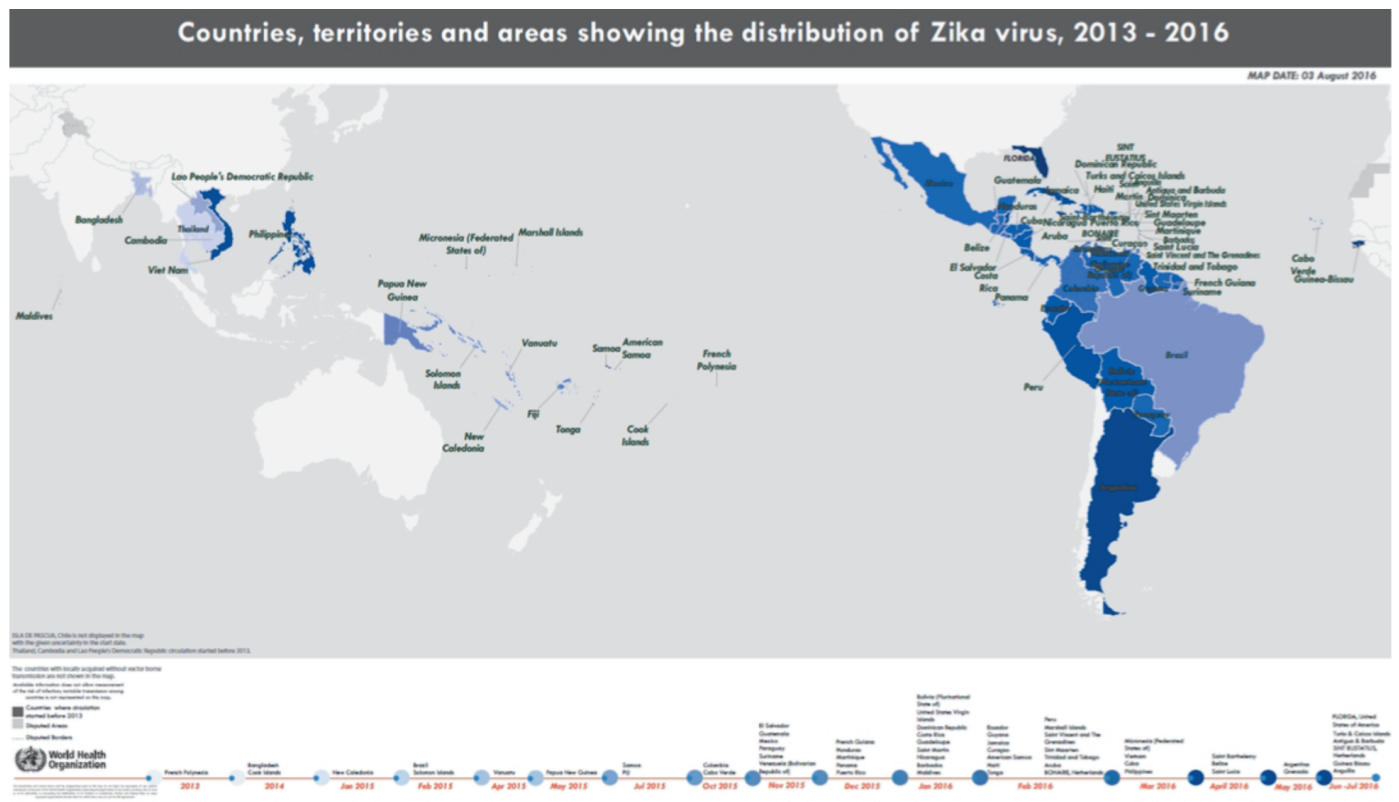

Figure: Countries, territories and areas showing the distribution of Zika virus, 2013-2016.

Zika virus is spread primarily by the bite of the Aedes aegypti and less likely from the Aedes albopictus mosquitoes, which may also transmit Dengue, Chikungunya and Yellow Fever. However, the common Culex mosquito is now being implicated (4). In addition to mosquito transmission, ZIKV can be transmitted vertically from the mother to the fetus, through sexual activity and blood transfusion; although less frequently, exposure to saliva, urine, tears and a laboratory accident have also been implicated (5-12). Attack rates of ZIKV in populations are high, approaching $66 \%$ to $73 \%$ in the French Polynesian and Yap island epidemics $(13,14)$. The multiple modes of transmission through mosquito bites and exposure to blood and body fluids, with the possibility of re-infection, means that once the virus enters a population it is likely to become endemic. Further, the co-circulation of ZIKV with other arboviruses, particularly Dengue and Chikungunya, not only presents challenges with respect to the similar clinical presentations and the laboratory diagnostics due to cross-reactivity in serological tests, but may potentially be important in understanding the pathogenesis and epidemiology of ZIKV infection.

Clinical features of ZIKV infection are present in 15$20 \%$ of adult cases and are generally mild, comprising primarily a generalized maculo-papular rash, joint and muscle pain, headache, non-purulent conjunctivitis and low grade, or no fever. While the majority, 80-85\%, of ZIKV infections are asymptomatic. Treatment is supportive and as yet, there is no vaccine, or recognized therapeutic cure. During the French Polynesia outbreak, the post-infectious neurological complication, notably Guillain-Barre Syndrome was first documented (15). These patients presented with acute motor axonal neuropathy and rapid evolution of their disease. Clinical features include generalized muscle weakness, inability to walk, facial nerve palsy and increased cerebrospinal fluid proteins; about $30 \%$ required ventilator support, which was prolonged. Countries are therefore increasing their intensive care bed capacity to better manage the expected high burden of patients with Guillain-Barre syndrome.

Until reports of an unexpected surge in congenital microcephaly coinciding with the ZIKV outbreak in Brazil started emerging in September 2015, there had been no prior indication of adverse outcomes associated with ZIKV infection in pregnancy, although a subsequent retrospective study in French Polynesia identified microcephaly cases with temporal association with the ZIKV outbreak there (5). Prenatal ZIKV infection has now been conclusively linked as with a cause of adverse pregnancy outcomes, including spontaneous abortions, stillbirths, intrauterine growth retardation, severe microcephaly and other brain lesions (16). Case reports, case series and epidemiologic studies of microcephaly associated with laboratory confirmed ZIKV infections confirm that the timing of "The Congenital ZIKV Syndrome" appears consistent with the "Fetal Brain Disruption Sequence" with microcephaly, redundant scalp skin, eye findings, arthrogryposis and clubfoot (17).

The rare exposure to the rare outcome of microcephaly, has been confirmed in travelleers who spent limited time in areas with active ZIKV transmission (18). Zika virus has also been isolated from glial cells and neurons of newborns with microcephaly (19). Estimated risks of severe microcephaly from infants infected primarily in the first trimester range from $1-30 \%$ in the French Polynesian and Brazilian epidemics (58). A more disturbing recent report from Brazil concerns infants who are exposed to ZIKV in late pregnancy, who are born with a normal head circumference, but later develop microcephaly by six months of age (20). 
Once ZIKV enters a population, about $70 \%$ of pregnant women would be expected to develop ZIKV infection $(13,14)$. However, the identification of such women is very difficult. While $20 \%$ of cases maybe symptomatic and maybe identified by ZIKV polymerase chain reaction testing, the symptoms may be mild, nonspecific and their significance maybe entirely missed (6). The remaining $80 \%$ are asymptomatic. In this latter group, the ZIKV serological tests (IgM and $\operatorname{IgG}$ ) are being explored; however these may be falsely positive for ZIKV in areas of the world, like the Caribbean, where Dengue and Yellow Fever, are also circulating. Neutralizing antibodies may be used in these settings for clarification, but these assays are still very difficult to be used successfully. Similarly, laboratory identification of the ZIKV-infected infant at birth is currently very challenging.

Recommendations for the management of pregnancy in ZIKV endemic areas are still very general (21). All women are being advised to protect themselves from mosquito bites and practice barrier contraceptives during sexual intercourse. Pregnant women are being asked to consult their physicians and to be evaluated for historical exposure to ZIKV infection followed by clinical evaluation, uterine ultrasounds, laboratory and other tests, as appropriate, at every antenatal visit (20). Reproductive health rights should be considered, in addition to the legal, ethical, religious, cultural, political, social, medical and other issues that must be weighed for any interventions, in each country, jurisdiction, or population, regarding the management of ZIKV infection in pregnancy.

Broad preventive measures for the general population include the recommendation to delay pregnancy for at least two months after a ZIKV infection (21). Others have advised women to delay pregnancy for up to two years. However, this may be ineffective as over $50 \%$ of all pregnancies maybe unplanned, some $20 \%$ of pregnancies may occur in youth, while many others may be forced. Similarly, men are advised to wear a condom during sexual activity for up to six months after possible ZIKV exposure and the virus has been isolated from semen for over 60 days (22). However, most of these suggestions are really impractical. Countries are preparing by educating their populations about Zika V and vector control, stopping the breeding of mosquitoes in stagnant water, while others are releasing the Wolbachia-infected Aedes aegypti mosquito as a research initiative to eradicate the mosquito.

Important research questions remain to be answered. These may include understanding the full spectrum of birth defects caused by congenital ZIKV infections, clarifying the risks to infants who are born to women who are exposed to ZIKV at different time points before and during pregnancy and identifying the factors that may modify pregnancy outcomes (including previous infection with dengue, or chikungunya fever). Clinical trials of drugs and ZIKV vaccines, similar to the recently developed dengue fever vaccine, are also urgently needed to be rapidly developed, scaled-up for testing in large placebo-controlled human trials and approved for use, to urgently deflect the dreaded complications of ZIKV and espe- cially, the development of future generations of children, worldwide, with significantly diminished neuro-developmental potential.

These and other important epidemiological questions can be answered through large, multi-country, population-based, research consortia, like "ZIKAction". This involves several research sites in Europe, Latin America and the Caribbean (including The University of the West Indies) which is led by the Pediatric European Network for Treatment of AIDS and Infectious Diseases (PENTA-ID) Foundation and was recently funded by the European Commission. A better understanding of ZIKV epidemiology, vertical transmission, risks to the fetus of maternal ZIKV infection and natural history of both congenital and non-congenital ZIKV infection provided by the "ZIKAction" activities is needed. This will identify potential interventions to prevent, or to decrease ZIKV acquisition and mitigate infection-induced damage, to inform evidence-based guidelines regarding clinical management of ZIKV infection of various types, to facilitate development of effective and appropriate surveillance systems and public health responses, as well as to provide important real-time information for health care planners and providers and policy-makers.

The University of the West Indies Regional Headquarters, therefore, welcomes wholeheartedly the 60 researchers from Europe, Latin America and the Caribbean who will be meeting in Jamaica for the "ZikAction Kick-Off Research" Conference from Sunday, October 30 to November 1, 2016, even as Jamaica responds simultaneously to its ZIKV epidemic (23).

\section{REFERENCES:}

1. WHO Sep 1, reference, viz: Zika Virus, Microcephaly and Guillain-Barre Syndrome. Situation Report. 1 September 2016. World Health Organization. http://apps.who.int/iris/bitstream/10665/249597/1/zikasitrep1Sept 16-eng.pdf?ua=1 (Accessed 10 September, 2016).

2. Zanluca C, de Melo VCA, Mosimann ALP, dos Santos GIV, dos Santos CND, Luz K. First report of autochthonous transmission of Zika virus in Brazil. Mem Inst Oswaldo Cruzl 2015: 110: 569-72.

3. Chan M. WHO Director-General summarizes the outcome of the Emergency Committee on regarding clusters of microcephaly and Guillain Barre syndrome. 1 February, 2016. www.who.int/mediacentre/news/ statements/2016/emergency-committee-zika-microcephaly/en/Accessed 14 August, 2016.

4. Franca RFO, Neves MHL, Ayres CFJ, Melo-Neto OP, Filho SPB. First International Workshop on Zika Virus held by Oswaldo Cruz Foundation FIOCRUZ in Northeast Brazil March 2016-a meeting report. PLoS Negl Trop Dis. 2016; 10: e0004760. DOIPubMed.

5. Cauchemez S, Besnard M, Bornpard P, Dub T, Guillermette-Artur P, Eyrolle-Guignot D Salje H et al. Association between Zika Virus and microcephaly in French Polynesia, 2013-2015: a retrospective study. Lancet 2016; 387: 2125-32.

6. Brasil P, Pereira J, Gabaglia CR, Damasceno L, Wakimoto M, Nogueira, et al. Zika virus infection in pregnant women in Rio de Janeiro - preliminary report. N Engl J Med, March 4, 2016/DOI: 10; 1056/NEJMoa1602412

7. Johansson MA, Teran-Momero LM, Reefhuis J, Gilboa S, Hills S. Zika and the risk of microcephaly. N Engl J Med 2016; 375: 1-4. 
8. Besnard M, Lastere S, Teissier A, Cao-Lormeau V, Musso D et al. Evidence of perinatal transmission of Zika virus, French Polynesia, December 2013 and February 2014 . Euro Surveill; 2014; 19(13): 20751.

9. Hill SL, Russell K, Hennessey M, Williams C, Oster AM, Fischer M et al. Transmission of Zika virus through sexual contact with travelers to areas of ongoing transmission - Continental United States, 2016. MMWR Morb Mort Wkly Rep 2016; 65: 215-216.

10. Vasquez, Amber M. Sapiano, Mathew RP, Basavaraju, Sridhar V. Kuehnert MS, Rivera-Garcia B, et al. (2016). Survey of blood collection centers and implementation of guidance for prevention of transfusiontransmitted Zika-Virus infection - Puerto Rico, 2016. MMWR. Morbidity and Mortality Weekly Report. 2016; 65: 375-378. doi:10.15585/ mmwr.mm6514e1. ISSN 0149-2195. PMID 27078190.

11. Centers for Disease Control and Prevention. Transmission of Zika Virusvirus. www.cdc.gov/zika/transmission, accessed 14 August, 2016.

12. Bonaldo MC, Ribeira IP, Lima NS, dos Santos AA, Menezes LS, da Cruz $\mathrm{SO}$, et al. Isolation of infective Zika Virus virus in the urine and saliva patients in Brazil. PLOS Neglected Tropical Diseases, 24 June, 2016, http://dx.doi.org/10.1371/journal.pntd.0004816, accessed 17 August, 2016.

13. Aubry M, Teissier A., Roche C, Brouit J, et al. Serosurvey of Dengue, Zika and other mosquito-borne viruses in French Polynesia. 64 ${ }^{\text {th }}$ Annual Meeting of the American Society of Tropical Medicine and Hygiene, Philadelphia, PA, USA. 2015: Oct 25-29, 2015.

14. Duffy MR, Chen TH, Hancock WT, Powers AM, Kool JL, Lanciotti RS et al. Zika virus outbreak on Yap Island, Federated States of Micronesia. N Engl Jour Med 2009; 360: 2536-2543.

15. Cao-Lormeau V, Blake A, Mons S, Lastère S, Roche C, Vanhomwegen J, Dub T et al. Guillain-Barré Syndrome outbreak associated with Zika virus infection in French Polynesia: a case-control study. Lancet 2016; 387: $1531-39$.
16. Rasmussen S, Jamieson DJ, Honein MA, Petersen LR. Zika virus and birth defects - reviewing the evidence for causality. N Engl J Med 2016; 374: 1981-1987.

17. Miranda-Filho Dde B, Martelli CM, Ximenes RA, Araujo TV, Rocha MZ, Ramos RC, et al. Initial description of the presumed congenital Zika syndrome. Am J Public Health 2016; 106: 598-600.

18. Meaney-Delman D, Hills SL, Williams C, Galang RR, Iyengar P, Hennenfent $\mathrm{AK}$ et al. Zika virus infection among US pregnant travelers - August 2015-February 2016. MMWR Morb Mortal Wkly Rep 2016; 65: $211-214$.

19. Mlakar J, Korva M, Tul N, Popovic M, Poljsak-Prijatelj M, Mraz J et al. Zika Virus associated with microcephaly. N Engl Jour Med 2016; 374: 951-958.

20. Pestorius T, Cesar V, Dobyns W, New Zika Threat to Infants: Late-Onset Microcephaly. http://click.mail.medscape.com/ ?qs=8d4d22f32693d8fe 078bf46315e62947056eeb8b59c40ac4f20b056a0600190d8639ca74816e 70b1, Accessed 14 August, 2016.

21. Oduyebo $\mathrm{T}$ et al. CDC updates guidance for clinical management of pregnant women infected with Zika. MMWR Mord Mort Wkly Rep. 2016; doi:10.15585/mmwr.mm6529el.

22. Barzon L, Pacenti M, Franchin E, Lavezzo E, Trevisan M, Sgarabotto D, Palù $\mathrm{G}$. Infection dynamics in a traveller with persistent shedding of Zika virus RNA in semen for six months after returning from Haiti to Italy, January 2016. Euro Surveill 2016; 21: pii=30316. DOI: http://dx.doi.org/ 10.2807/1560-7917. ES.2016.21.32.30316"

23. Webster-Kerr KR, Christie CDC, Grant A, Chin D, Burrowes H, Clarke $\mathrm{K}$. Emergence of Zika virus epidemic and the national response in Jamaica. West Indian Med J 2016 Sep 28. doi: 10.7727/wimj.2016.454. [Epub ahead of print]. 